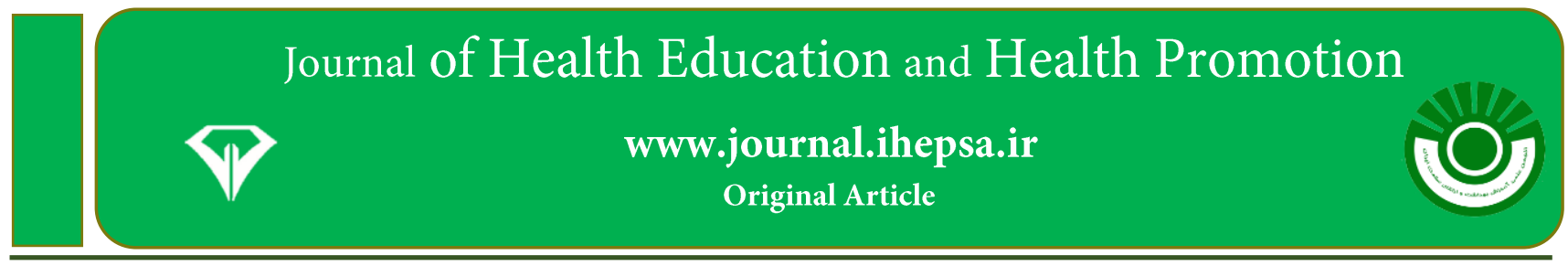

\title{
Relationship between Age, Gender and Body Mass Index with Performance of Fundamental Motor Skills among Children Aged 7-10 Years
}

\section{$\underline{\text { Amir Shams }}{ }^{1}$, Roshanak Vameghi $^{2}$}

1. Sport Science Research Institute (SSRI), Tehran, Iran

2. University of Social Welfare and Rehabilitation Sciences, Tehran, Iran

Article Information

\section{Article History:}

Received: 2016/09/05

Accepted: 2017/11/25

Available online: 2018/01/30

IJHEHP 2018; 6(1):039-052

\section{DOI:}

10.30699/acadpub.ijhehp.6.1.39

Corresponding Author:

\section{Amir Shams}

Sport Science Research Institute (SSRI), Tehran, Iran

Tel: 09127387472

Email:

amirshams85@gmail.com

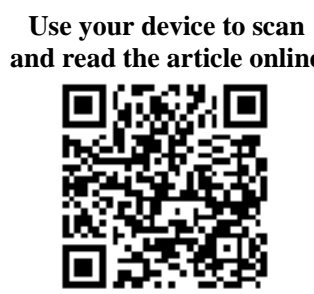

\section{Abstract}

Background and Objective: This study aimed to examine the relationship between age, gender and body mass index with performance of fundamental motor skills among children aged 7-10 years.

Methods: A total of 600 children aged 7-10 years from Tehran participated in this research. Body mass index was directly measured, dividing weight $(\mathrm{kg})$ by squared height $(\mathrm{m})^{2}$ for each child. Fundamental motor skills were assessed using the OSUSIGMA scale.

Results: The results showed that age and gender variables had a significant relationship on walking and running skills, but BMI was not significant $(P>0.05)$. Also age, gender and body mass index variables had a significant relationship on jumping, skipping, hopping and ladder climbing $(P<0.05)$. Age and BMI variables had a significant relationship on ladder climbing but gender variables was not significant. The results showed that age and gender variables had significant effect on catching and throwing skills but BMI was not significant for these skills. Finally the results showed that age, gender and BMI had a significant relationship on kicking and sticking skills. Also, this research demonstrated that boys performed better than girls.

Conclusion: Based on presented results, the need for educational programs in the field of play and physical activities seems necessary in elementary schools. If these programs are carefully implemented, can lead to increasing expertise in fundamental motor skills. Thus, increased playing and physical activities, will lead to reducing the prevalence of obesity and overweight in children.

KeyWords: Fundamental Motor Skills, Obesity, Children

Copyright () 2018 Iranian Journal of Health Education and Health Promotion. All rights reserved.

How to cite this article:

Shams A, Vameghi R. Relationship between Age, Gender and Body Mass Index with Performance of Fundamental Motor Skills among Children Aged 7-10 Years . Iran J Health Educ Health Promot. 2018; $6(1): 39-52$

Shams, A., Vameghi, R.(2018). Relationship between Age, Gender and Body Mass Index with Performance of Fundamental Motor Skills among Children Aged 7-10 Years . Iranian Journal of Health Education and Health Promotion, 6 (1) : 39-52 
ارتباط سن، جنسيت و شاخص تودهٔ بدنى با تبحر مهارتهاى حر كتى بنيادى

$$
\begin{aligned}
& \text { در كود كان لانا • ال سال } \\
& \text { امير شمس'؛ روشنك وامقى' }
\end{aligned}
$$

I. . يزوهشكاه تربيتبدنى و علوم ورزشى، تهران، ايران

\begin{tabular}{|c|c|}
\hline جكيده & اطلاعات مقاله \\
\hline 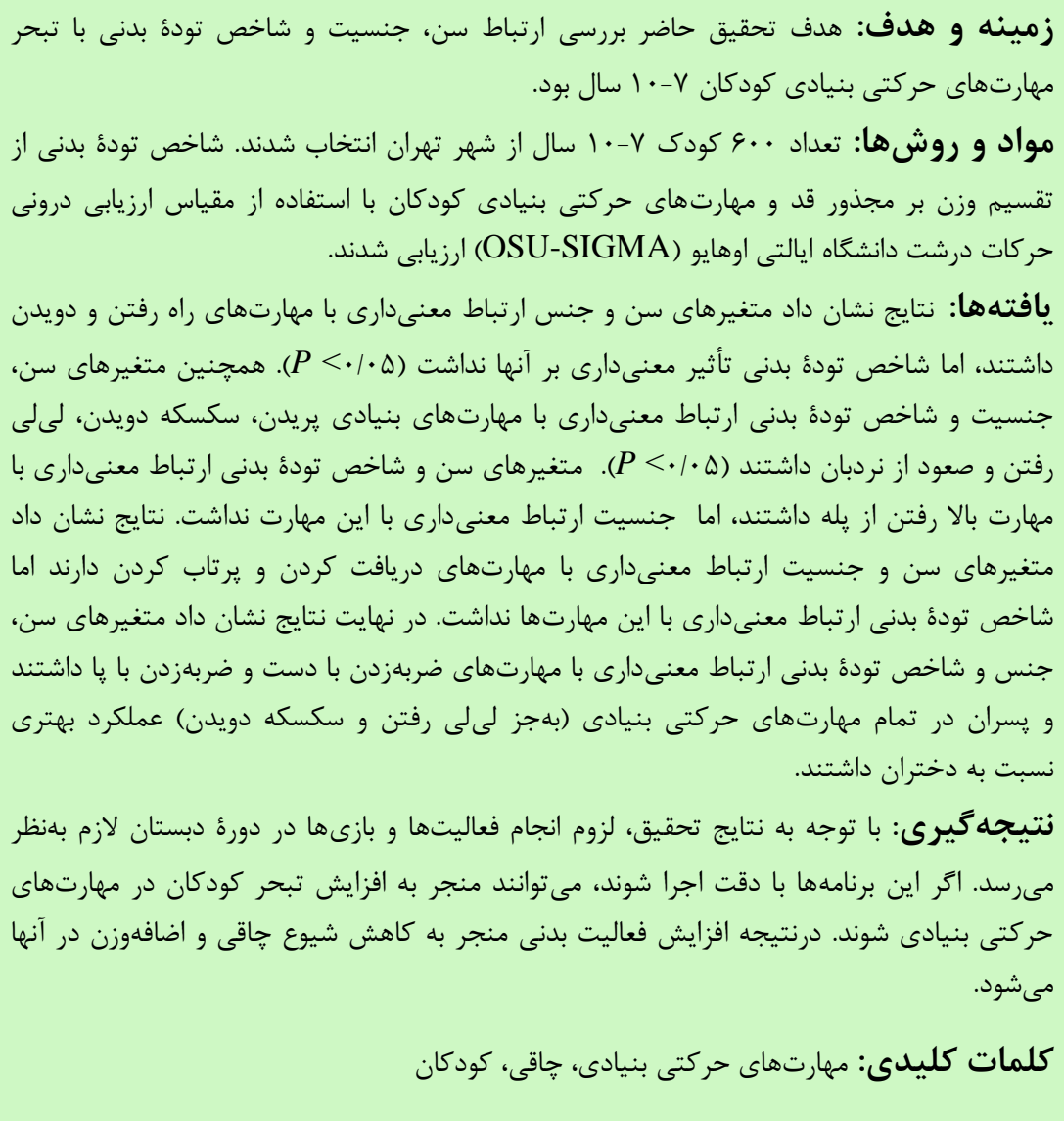 & 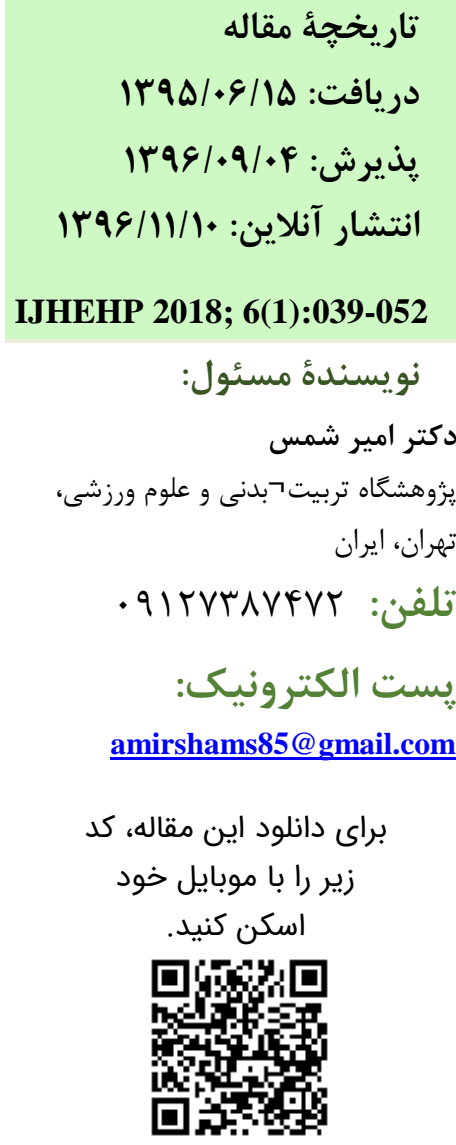 \\
\hline
\end{tabular}

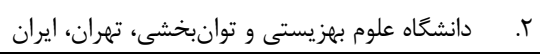

مقامله

كمتر بروز مى كردند. عوارض اين بيمارىها كه هم فرد و هم تمان

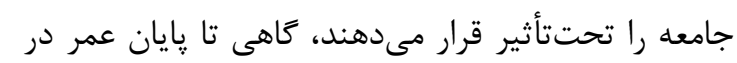

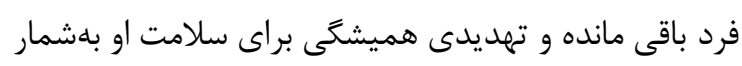

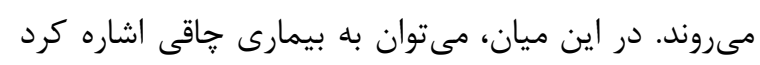

با توجه به كنترل اكثر بيمارىهاى واگيردار در سطح

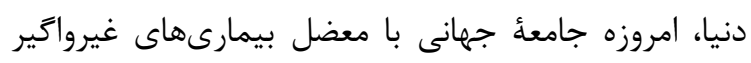

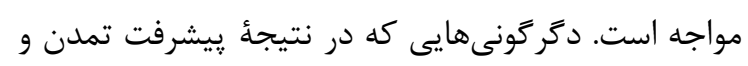

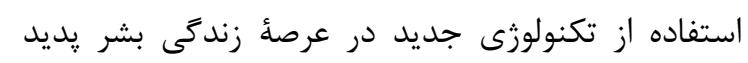

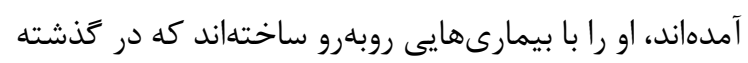


و بزركسالى مىشود (IV) (IV). تحقيقات مختلف نشان دادهاند كه نداشتن فرصتهاى كافى براى كسب تبحر در مهارتهاى حركتى بنيادى، موجب نرسيدن به موفقيت و

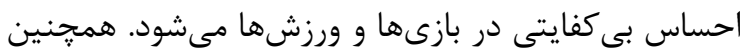
ارتباط اجتماعى كودكانى كه در انجام اين مهارتها تهارئا تبحر كافى ندارند، بهراحتى كودكان ماهر نيست (If). ضمن

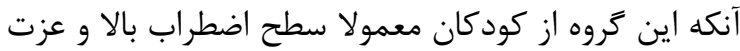

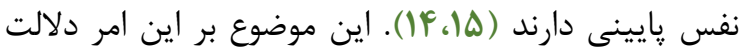

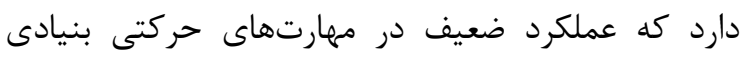

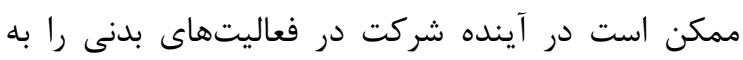

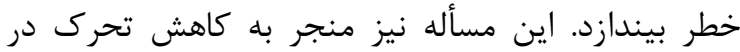

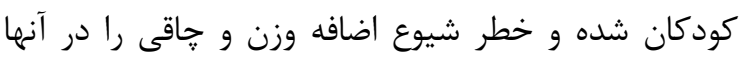
افزايش مى دهد (19، 11) (1).). از سوى ديگر محققان معتقدند علاوه بر اضافهوزن و

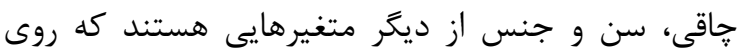

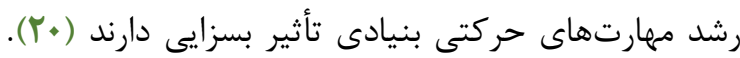

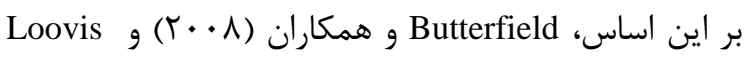

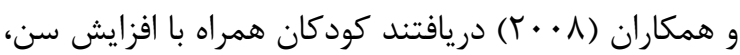
در اين مهارتها (ضربه زدن به توب و دريافت كردن) باليدهتر و ماهرتر مىشوند اما در اين دو مطالعه بين

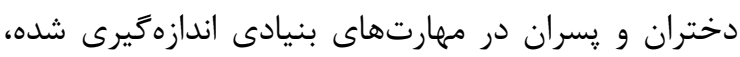

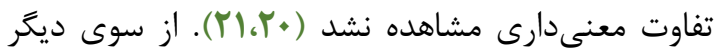
(199r) Butterfield Loovis

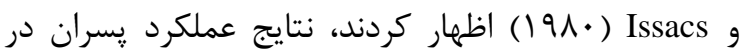

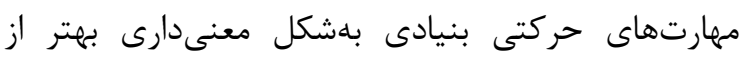

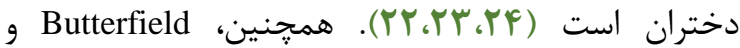

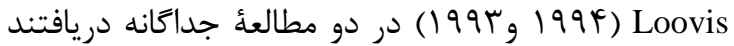

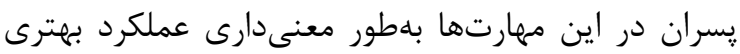

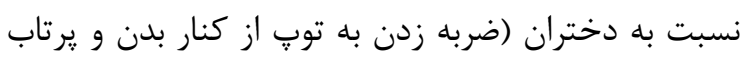

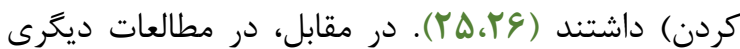

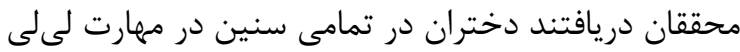

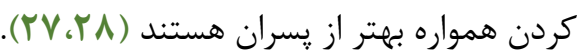
در اكثر تحقيقات انجام شده در اين زمينه، محققان جداكانه به بررسى تأثير عواملى مثل سن، جنس، جاتى تركيب بدنى بر مهارتهاى حركتى بنيادى :رداختهاند. جند تحقيقى كه تمامى اين عوامل را مدنظر قرار دادهاند بندي
كه بسيارى از بيمارىها از عوارض مستقيم و غيرمستقيم

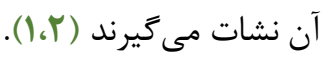

براساس نتايج مطالعات Ogden و همكاران (ع +. (Y) و D' Hondt

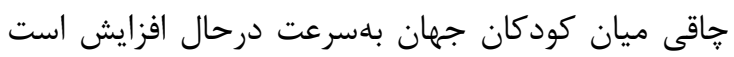

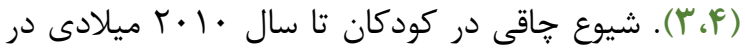

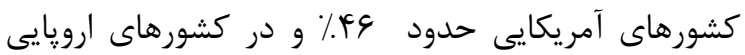

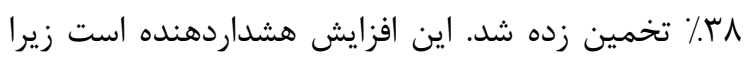

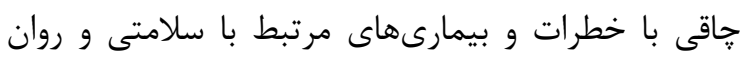

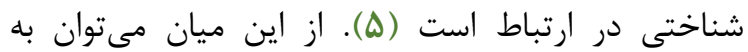

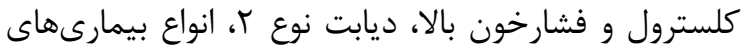

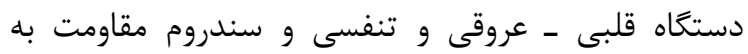

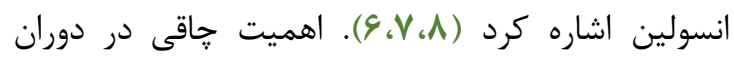
كودكى و نوجوانى نه فقط بهدليل عوارض جسمى و روانى زودرس، بلكه بهخاطر افزايش جاقى بزركسالى، افزايش

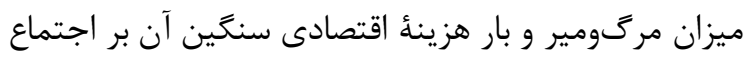

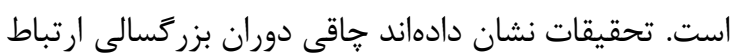
مستقيمى با خاقى دوران كودكى و نوجوانى دارد آنجنان آنان كه در كودكان خاق، شيوع خاقى بزر گسالى دو تا سه برابر

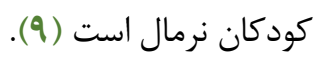

Tybor Must و همكاران (r) Morrison

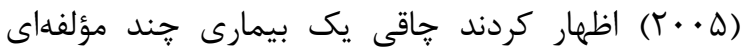

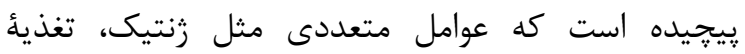

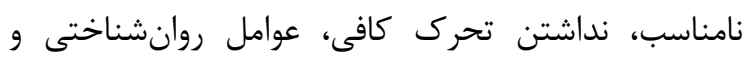
محيط كودى در بروز آن دخيل هستند. اين محققان

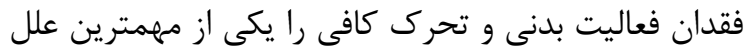

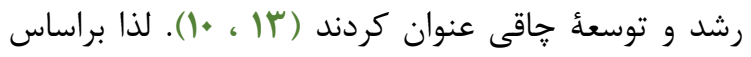
نظر محققان، عناصر اصلى رشد حركتى، علاوه بر زيربناى زيستشناختى آن، مهارتهاى حركتى بنيادى (FMS) است كه مهارتهاى حركتى درشت و ظريف مثل مهارت

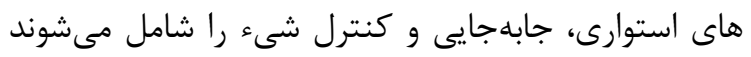
(1). (1). تبحر در مهارتهاى حركتى بنيادى در سالهاى

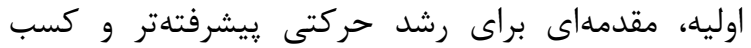

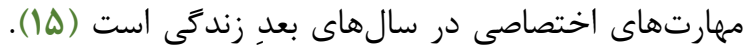
رشد نيافتن و اصلاح مهارتهاى حركتى بنيادى درى در داصن دوران

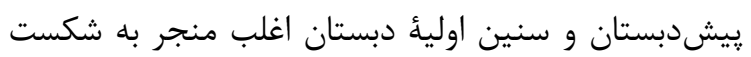
و توسعه نيافتن مهارتهاى حركتى ويزه در دوران نوجوانى 
نسبت (درصد) هر منطقه ضرب شد و حجم نمونهُ هر

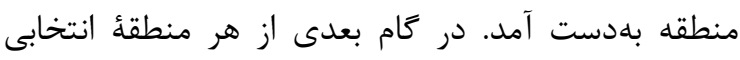
حداكثر سه دبستان و سه مركز بهداشت و تندرستى، بهدي، تصادفى انتخاب شدند. سيس برحسب درصد (نسبت) هر منطقه از مراكز بهداشتى و دبستانها تعداد افراد مدنظر سند

انتخاب شدند.

\section{ابزار جمع آورى اطلاعات}

قد هر كودك بدون كفش در حالت ايستاده و مستقيم

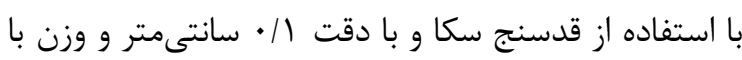
استفاده از ترازوى ديجيتال سكا و با دقت / / • كيلوگرم اندازهگيرى شد. سيس از تقسيم وزن (كيلوگرم) بر مجذور قد (مترمربع) شاخص توده بدنى (BMI) محاسبه شد. با سئ

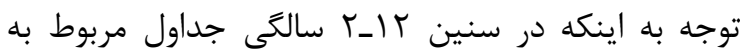

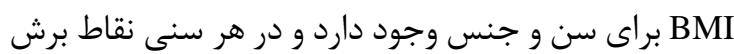
جاقى و اضافهوزن براى هر جنس متفاوت است، ابتدا براى هر جنس اعداد مربوطه مشخص شد سيس BMI هر هر

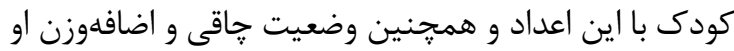
تعيين شد. براى تعيين اضافهوزن و جاقى، از صدكهاى

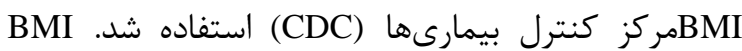
بالاتر از صدك هو بهعنوان خاقى، BMI بين هم تا له9 به

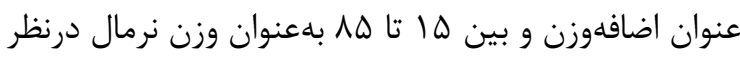

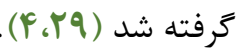

مهارتهاى حركتى بنيادى كودكان با استفاده از مقياس ارزيابى درونى حركات درشت دانشخاه ايالتى اوهايو

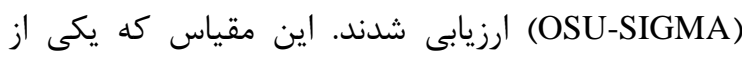

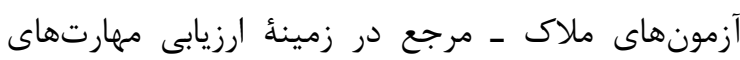

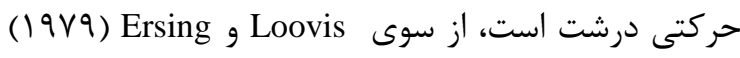
براى كودكان سالم و عقبمانده ذهنى در ايالات متحده

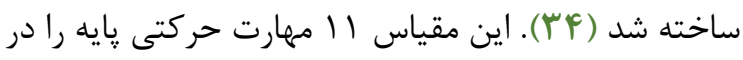
دو مقوله ا. مهارتهاى جابهجايى (مثل راه رفتن، دويدن، يريدن، لىلى رفتن، سكسكه دويدن، مهارت بالا رفتن از

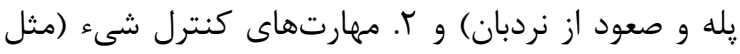
يرتاب كردن، دريافت كردن، ضربه زدن با دست و ورد ضربه

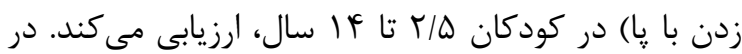

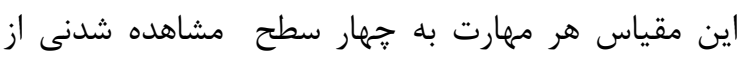

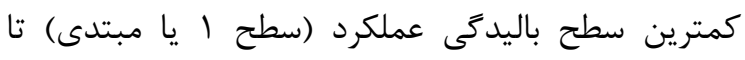
بيشترين سطح باليدگى عملكرد (سطح جهار يا پيشرفته) تقسيم و براساس راهنماى اجراى ميدانى مقياس هر

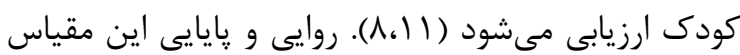

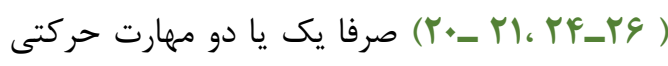

بنيادى (ضربه زنن، يرتاب كردن و دريافت كردن) را

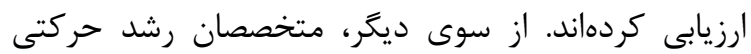

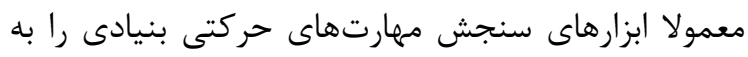

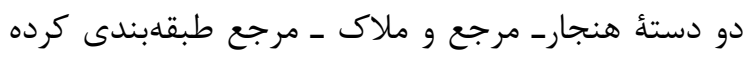

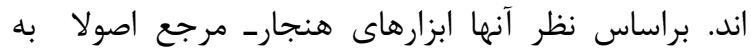
منظور ارزشيابى كمّى و مقايسُٔ توانايىها و مهارتهاى

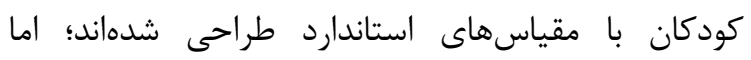
ابزارهاى ملاكى ـ مرجع ابزارهايى كيفى هستند كه موقعيت

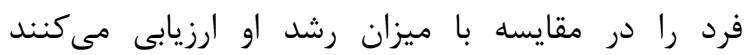

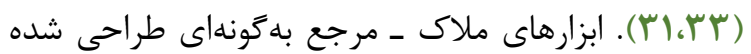
اند تا موقعيت كودكان روى ييوستار مهارتها و ترتيب

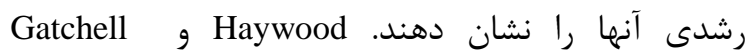

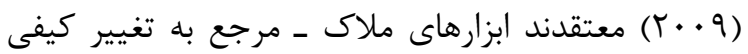

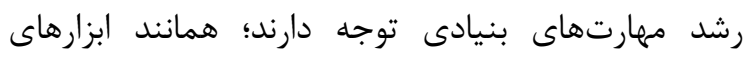
سنجش كمى شناخته نشدهاند و اغلب بلندرت از از آنها استفاده مىشود (سM). لذا انجام : يزوهشى جامع در اين زمينه بهويزه در كودكان ايرانى براى ارزيابى اين عوامل

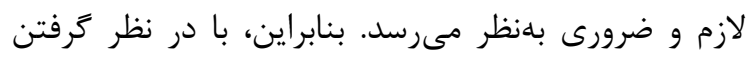

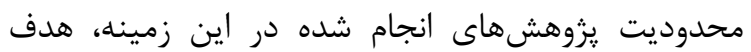
يزوهش حاضر تعيين ارتباط سن، جنسيت و شاخص توده

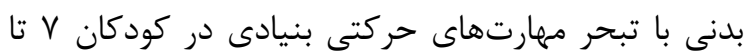

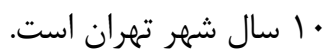

$$
\text { روش بروسى }
$$

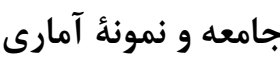

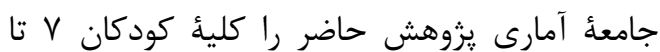
• ا سال شهر تهران تشكيل دادند. نمونه آمارى تحقيق شامل تعداد · .4 نفر از جامعة مدنظر بود كه بهصورت نمونه

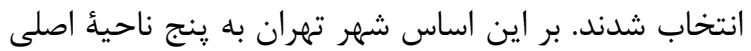
جغرافيايى (شرق، غرب، شمال، جنوب و مركز) تقسيهم و از هر ناحيءٔ جغرافيايى يك منطقه بهصورت تصادفى انتخاب

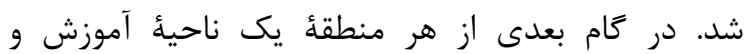
يرورش، بهصورت تصادفى انتخاب و با مشخص كردن

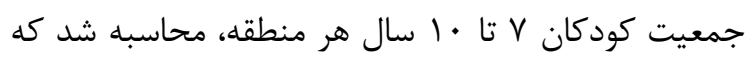

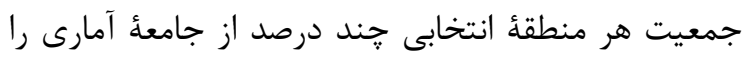
تشكيل مىدهد. سيس حجم انتخاب شده اوليه ( • •4 نفر) به مجموع درصدهاى بلدستآمده تقسيم و حاصل دئ در 


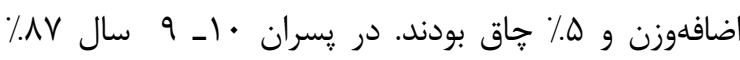

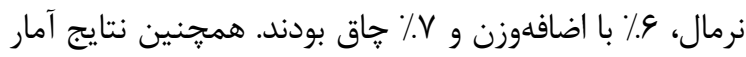
توصيفى در ارتباط با سطوح ييشرفت مهارتهاى حركتى

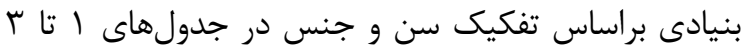

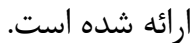

براساس نتايج ارائه شده در جدولهاى ا تا ب در گروه

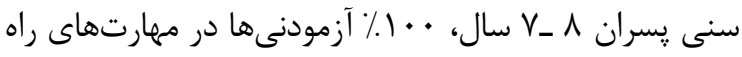

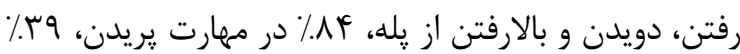

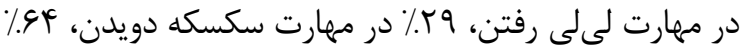

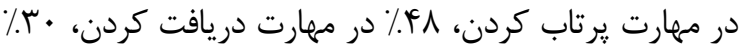

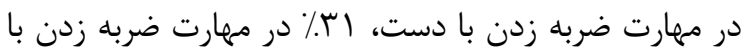

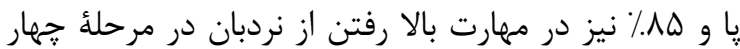

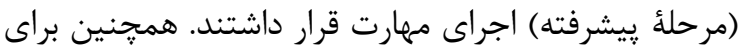

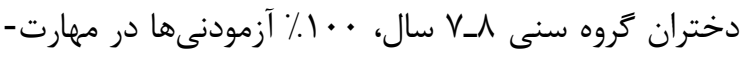

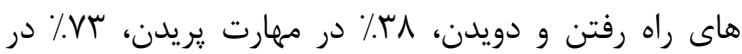

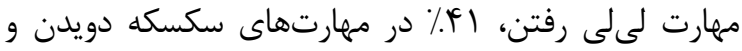

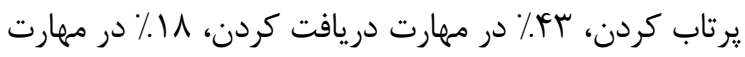

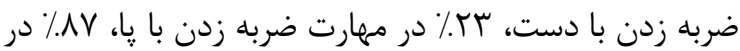

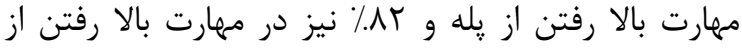

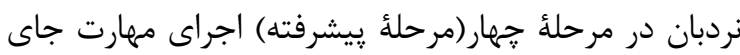
كرفتند.

براى يسران گروه سنى 9ـ ^ سال، . . 1\% آزمودنىها

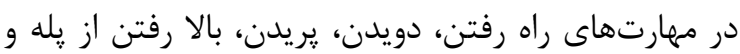

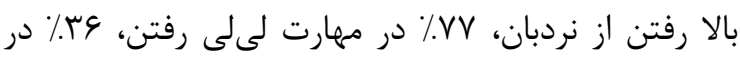

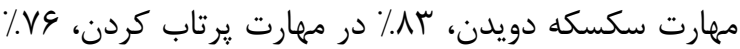
در مهارت دريافت كردن، ه\$\&

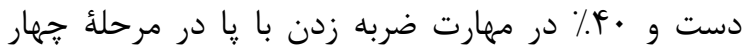
(مرحلة يِيشرفته) اجراى مهارت قرار داشتند. براى دختران

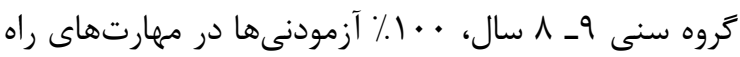

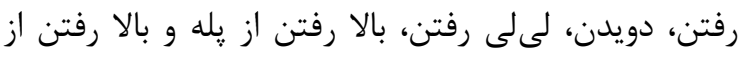

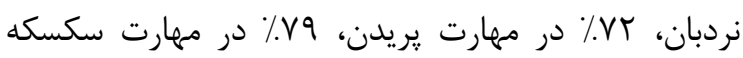

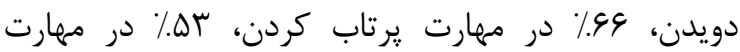

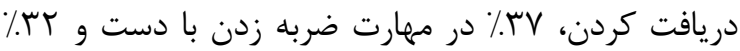

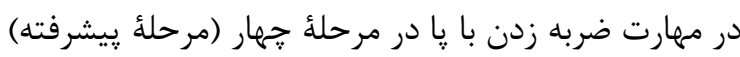

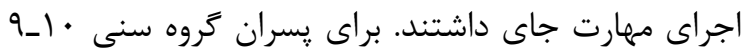

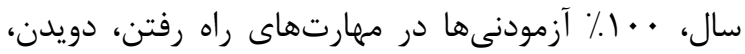

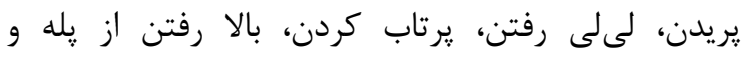

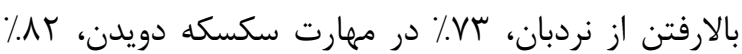

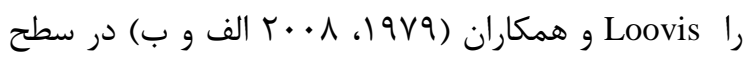
بسيار بالايى به دست آوردند (آז،•ا). در ايران نيز Vaneghi حد قابلقبولى كزارش كردند (Iآ).

\section{يروتكل اجراى تحقيق}

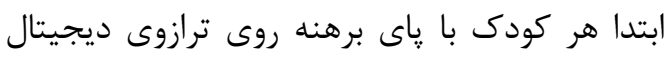

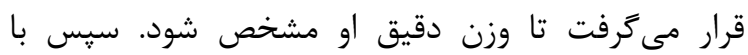
BMI استفاده از قدسنج، قد هر كودى اندازمخيرى شد أند

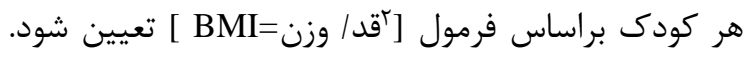
در اين فرمول قد به مترمربع و وزن براساس كيلوكرم است. درنهايت براساس BMI هر كودى و مقايسٔ آن با نرمهاى BMI مركز كنترل بيمارىها (CDC) صدك او مشخص و

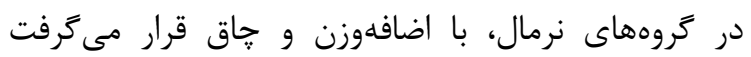

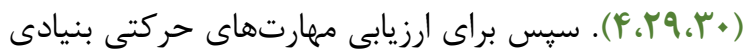
كودكان از 11 ارزياب ماهر استفاده شد. اين ارزيابها در

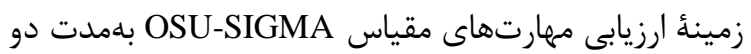

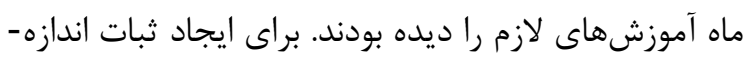
كيرى و نمرهدهى در هر مهارت اين مقياس، هر ارزياب يك الدان

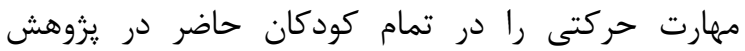

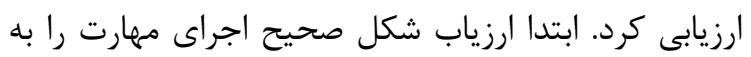

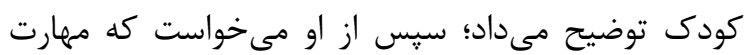
درنظر كرفته شده را اجرا كند. درنهايت براساس بركأ امتيازدهى، سطح اجراى مهارتى كه كودى در در آن قرانه داشت، تعيين مىشد.

\section{روش تحليل دادهها}

براى تحليل دادهها از روشهاى آمارى توصيفى

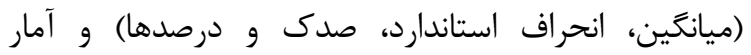

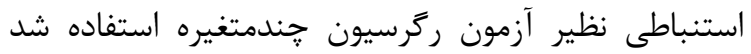

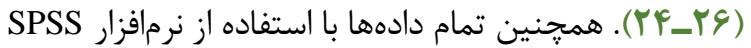
نسخه ها، در سطح معنى دارى ه • •>>P تحليل شدند.

يافتهها

نتايج آمار توصيفى در ارتباط با شاخص تودهٔ بدنى

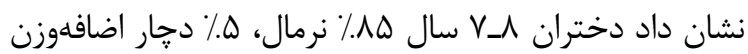

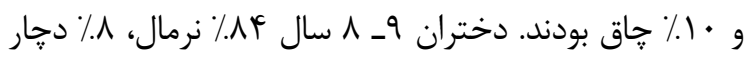

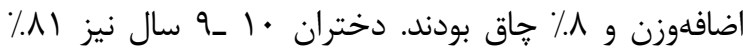

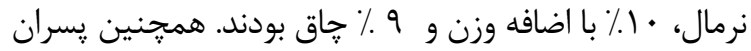

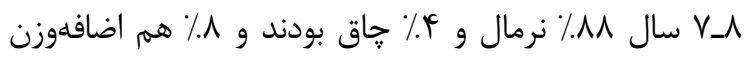

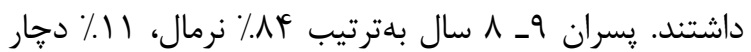




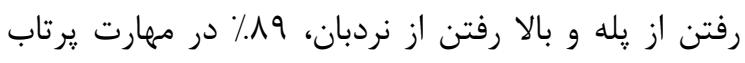

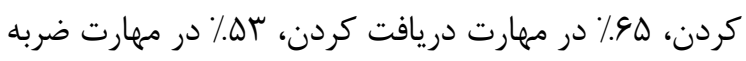

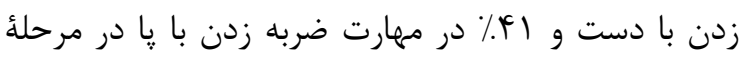

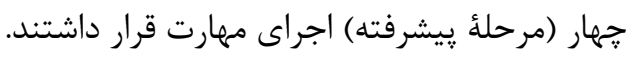

در مهارت دريافت كردن، 99\% در مهارت ضربه

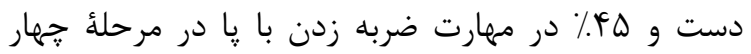

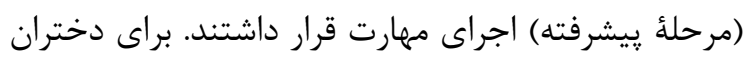

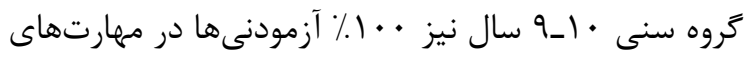

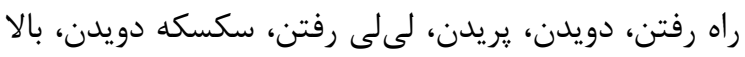

جدول ا. سطوح ييشرفت ل/ مهارت حركتى بنيادى در دختران و يسران V-1 سال

\begin{tabular}{|c|c|c|c|c|}
\hline \multicolumn{5}{|c|}{ سطح بيشرفت هر مهارت در دختران V-^ سال } \\
\hline سطح r & سطح r & سطح r & سطح 1 & مهارت هاى حركتى بنيادى \\
\hline 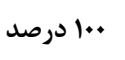 & ------ & -------- & --------- & اه رفتن \\
\hline 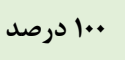 & ------ & -------- & ------- & 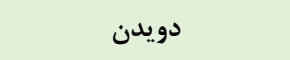 \\
\hline 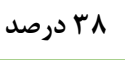 & 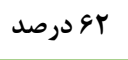 & ----- & ------- & 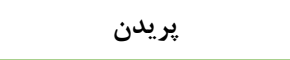 \\
\hline 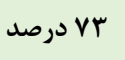 & 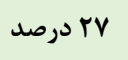 & ------ & ------ & 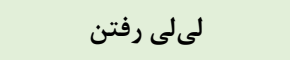 \\
\hline 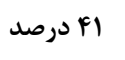 & ه د درصد & ------- & ------- & 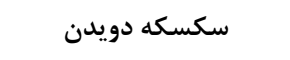 \\
\hline 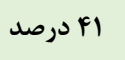 & ه د درصد & ------- & ------- & بالا رفتن از يله \\
\hline 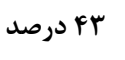 & 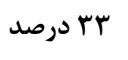 & 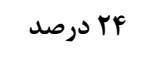 & ------- & 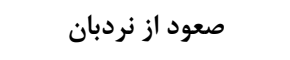 \\
\hline 1 | 1 ادرصد & 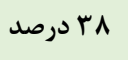 & L درصد FF & ------- & 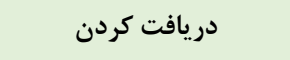 \\
\hline r بr درصد & 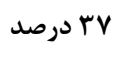 & 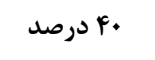 & ------- & 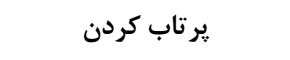 \\
\hline 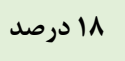 & 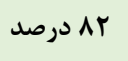 & ------- & ------- & 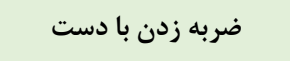 \\
\hline 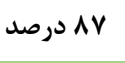 & rادرصد & ----- & ------ & ضربه زدن با پا \\
\hline \multicolumn{5}{|c|}{ سطح پيشرفت هر مهارت در يسران V-1 سال } \\
\hline سطح i & سطح r & سطح r & سطح 1 & مهارتهاى حركتى بنيادى \\
\hline 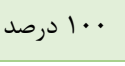 & ------ & ------- & ------ & راه رفتن \\
\hline ل & ----- & -------- & ------- & 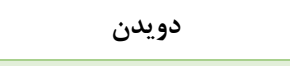 \\
\hline ل & عا درصد & ----- & ------ & 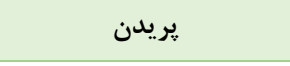 \\
\hline جr درصد & اع درصد & ----- & ------ & ل لى لى رفتن \\
\hline ج ج درصد & ا ل الVدصد & ----- & ------ & سكسكه دويدن \\
\hline 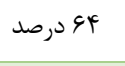 & عب درصد & ------ & ------ & بالا رفتن از يله \\
\hline ل & qج درصد & ما درصد & ----- & صعود از نردبان \\
\hline 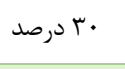 & عب درصد & F & ----- & دريافت كردن \\
\hline ابr درصد & F F درصد & S Ta & ----- & ير ت باب كردن \\
\hline ل مي درصد & ل ال درصد & ----- & ------ & ضربه زدن با دست \\
\hline ل & ------ & ----- & ------ & ضربه زدن با پا \\
\hline
\end{tabular}


جدول ז. سطوح بِيشرفت |/ مهارتهاى حركتى بنيادى در دختران و پِّران 9-1 سال

\begin{tabular}{|c|c|c|c|c|}
\hline \multicolumn{5}{|c|}{ سطح بيشرفت هر مهارت در دختران 9-1 سال } \\
\hline 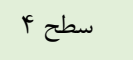 & 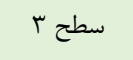 & 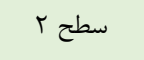 & 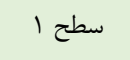 & مهارتهاى حركتى بنيادى \\
\hline 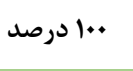 & ----- & -------- & ------- & راه رفتن \\
\hline 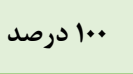 & ------ & -------- & ------- & 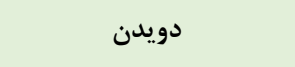 \\
\hline 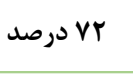 & 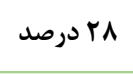 & ----- & ------ & 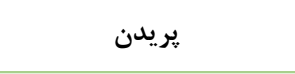 \\
\hline 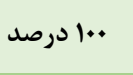 & ------ & ------ & ------ & 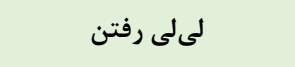 \\
\hline 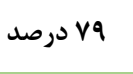 & ا الr درصد & ----- & ----- & سكسكه دويدن \\
\hline 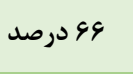 & 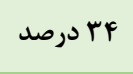 & ------ & ------ & بالا رفتن از يله \\
\hline 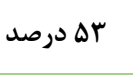 & 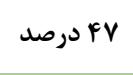 & ------ & ------ & صعود از نردبان \\
\hline 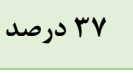 & ا ل اله درصد & ل المادرصد & ----- & 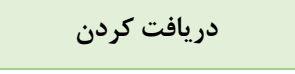 \\
\hline 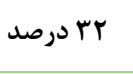 & 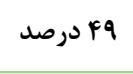 & ا & ------ & 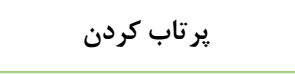 \\
\hline 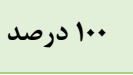 & ------ & ------ & ------ & ضربه زدن با دست \\
\hline 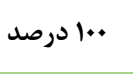 & ----- & ----- & ----- & ضربه زدن با با \\
\hline \multicolumn{5}{|c|}{ سطح بيشرفت هر مهارت در يسران 9-1 سال } \\
\hline 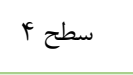 & 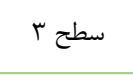 & 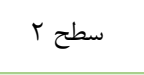 & 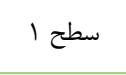 & مهيارتهاى حركتى بنيادى \\
\hline 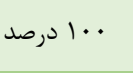 & ----- & ------ & ----- & راه رفتن \\
\hline 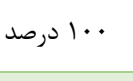 & ----- & ------- & ----- & 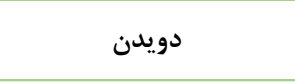 \\
\hline 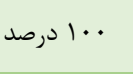 & ----- & ----- & ------ & 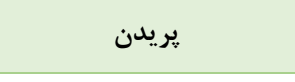 \\
\hline 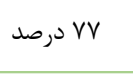 & 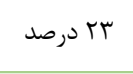 & ----- & ----- & 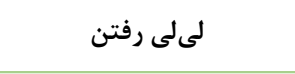 \\
\hline 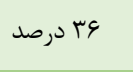 & 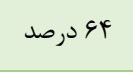 & ------ & ------ & سكسكه دويدن \\
\hline 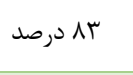 & 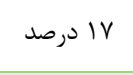 & ----- & ----- & 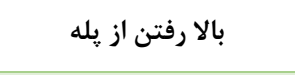 \\
\hline 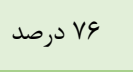 & 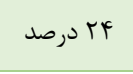 & ------ & ----- & صعود از نردبان \\
\hline 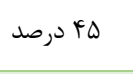 & 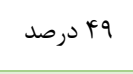 & 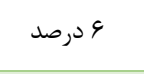 & ----- & 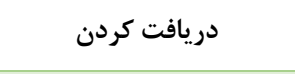 \\
\hline ل ز مرصد & لو مرصد & ل المرصد & ------ & بر تاب كردن \\
\hline ل ا. ا درصد & ----- & ----- & ---- & ضربه زدن با دست \\
\hline 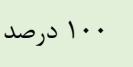 & ----- & ---- & ------ & ضربه زدن با با \\
\hline
\end{tabular}


جدول ". سطوح پِيشرفت || مهارتهاى حركتى بنيادى در دختران و يسران •|-9 سال

\begin{tabular}{|c|c|c|c|c|}
\hline \multicolumn{4}{|c|}{ سطح بيشرفت هر مهارت در دختران •1-9 سال } & \multirow[b]{2}{*}{ مهارتهاى حركتى بنيادى } \\
\hline سطح f & سطح r & سطح r & سطح 1 & \\
\hline 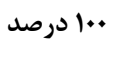 & ------ & -------- & ------- & راه رفتن \\
\hline 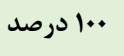 & ------ & -------- & ------- & 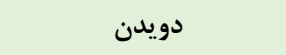 \\
\hline 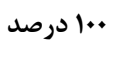 & ------ & ------ & ------- & 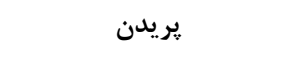 \\
\hline 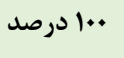 & ------ & ------ & ------ & 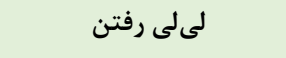 \\
\hline 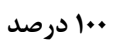 & ------ & ------ & ------ & 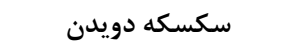 \\
\hline 19 1 درصد & ال ال درصد & ------ & ------ & بالا رفتن از يله \\
\hline 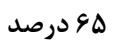 & هץ درصد & ------ & ------ & صعود از نردبان \\
\hline r مه درص & FV درصد FV & ------ & ------ & دريافت كردن \\
\hline 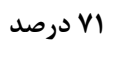 & r r درصد & V V V V V & ------ & ير تاب كردن \\
\hline 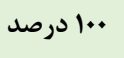 & ------ & ------ & ------ & ضربه زدن با دست \\
\hline ل · •ا درصد & ------ & ------ & ------ & ضربه زدن با ها \\
\hline & 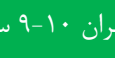 & سطح بيشر & & \\
\hline سطح f & سطح r & سطح r & سطح 1 & مهارت هاى حركتى بنيادى \\
\hline 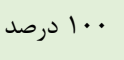 & ------ & -_------ & ------- & راه رفتن \\
\hline • • ا درصد & ------ & -------- & ------- & 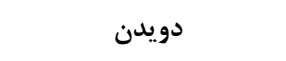 \\
\hline ا درصد & ------ & ------ & ------- & 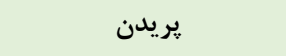 \\
\hline • • ا درصد & ------ & ------- & ------ & ل لى لى رفتن \\
\hline س Vرصد & V V T د صد & ------ & ------ & سكسكه دويدن \\
\hline • • 1 درصد & ------ & ------ & ----- & بالا رفتن از یله \\
\hline T T درصد & | | درصد & ------ & ------ & صعود از نردبان \\
\hline و و درصد & اس درصد & ----- & ----- & دريافت كردن \\
\hline F F Fر ند & م ه درصد & ----- & ----- & ير تاب كردن \\
\hline • · ا درصد & ----- & ----- & ----- & ضربه زدن با دست \\
\hline 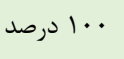 & ------ & ----- & ------ & ضربه زدن با پا \\
\hline
\end{tabular}

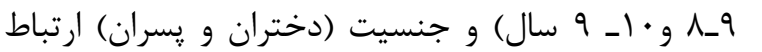

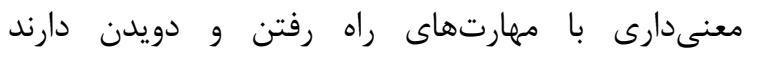
(P<0.05)
نتايج آمار استنباطى در ارتباط با هفت مهارت

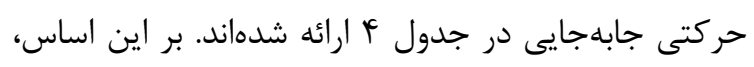

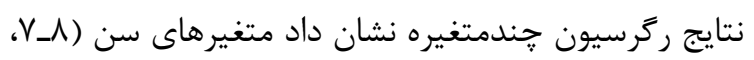


همجنين، نتايج آمار استنباطى در ارتباط با جهار مهارت حركتى كنترل شىء در جدول گنج ارائه شدهاند. بر اين اساس، نتايج ركرسيون جندمتغيره نشان داد متغيرهاى

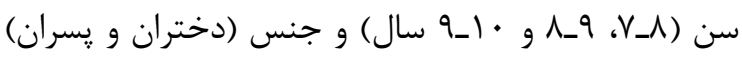
تأثير معنىدارى بر مهارتهاى دريافت كردن و زيرتاب

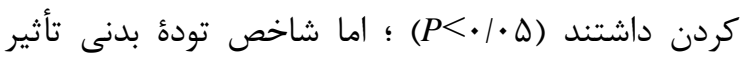

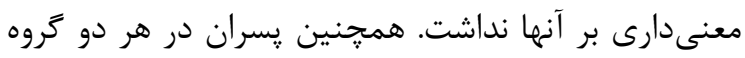

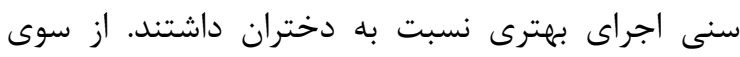
ديخر، نتايج رگرسيون جندمتغيره نشان داد كه متغيرهاى

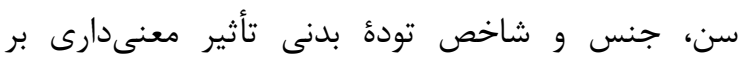

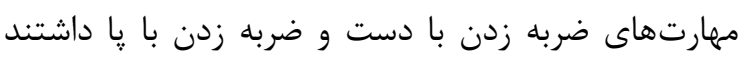

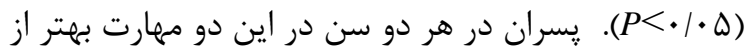
دختران بودند. همجنين در هر دو جنس كودكان با اضافه-

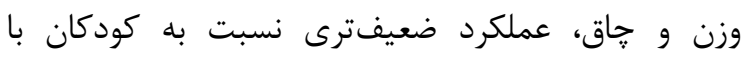
شاخص توده بدنى نرمال داشتند.
نداشت. علاوه بر اين، يسران در هر سه گروه سنى اجراى

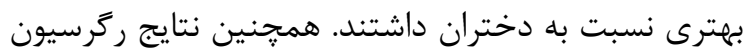
جندمتغيره نشان داد كه متغيرهاى سن، جنس و شاخص توده بدنى، ارتباط معنى دارى با مهارتهاى يريدن، سكسكه

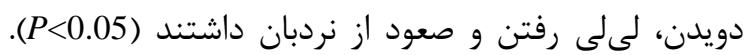

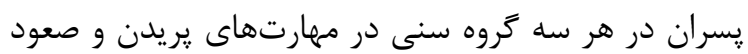

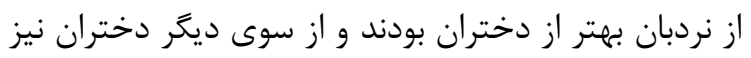

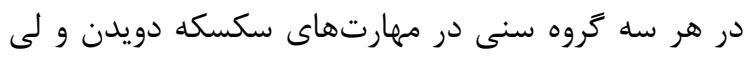
لى رفتن عملكرد بهترى نسبت به يسران داشتند. همجنين در هر دو جنس، كودكان با اضافه وزن و و جاق عملكرد ضعيفترى نسبت به كودكان با شاخص تودهٔ بدنى نرمال

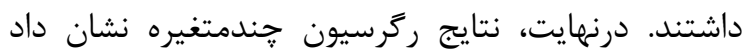
متغيرهاى سن و شاخص توده بدنى ارتباط معنى دارى با

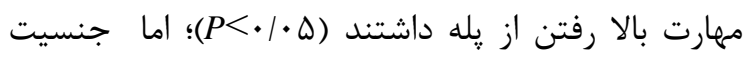
تأثير معنى دارى بر اين مهارت نداشت. لذا دختران و پيسران در اين مهارت تفاوت معنى دارى با يكديخر نداشتند.

جدول F. تحليل ركرسيون קندمتغيره براى هفت مهارت جابهجايى با متغيرهاى سن، جنسيت و شاخص توده بدنى (BMI) در كودكان • V_l سال

\begin{tabular}{|c|c|c|c|c|c|c|}
\hline \multicolumn{3}{|c|}{ متغير هاى مستقل } & \multirow{2}{*}{ Df } & \multirow{2}{*}{$\mathbf{F}$} & \multirow{2}{*}{$\mathbf{R}^{2}$} & \multirow{2}{*}{ متغير هاى وابسته } \\
\hline BMI & جنس & 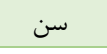 & & & & \\
\hline & & & $\Delta 99$ & $4 \cdot / 9 T \Delta$ & $.1 \cdot 90$ & راه رفتن \\
\hline.$- / \cdot \wedge f$ &.$/ 190^{*}$ & $\cdot / 1 \wedge \Delta^{*}$ & & & & ضر يب استاندارد نشده (b) \\
\hline \multirow{2}{*}{$-\cdot \mid \cdot 11$} & $\cdot / 194 *$ & $\cdot / / \gamma k^{*}$ & & & & ضريب استاندارد شده (Beta) \\
\hline & & & $\Delta 99$ & $9 / \wedge r$ & $.1 .9 \Delta$ & ل دويدن \\
\hline$\cdot / \cdot r \cdot$ & $\cdot / / \uparrow \xi *$ & $\cdot r \cdot r *$ & & & & ضر يب استاندارد نشده (b) \\
\hline \multirow[t]{2}{*}{$\cdot / \cdot r 1$} & $\cdot / / F \Delta *$ & $\cdot / r \cdot \Delta *$ & & & & ضريب استاندارد شده (Beta) \\
\hline & & & $\Delta 99$ & VG/ATD & $\cdot / 4 V 9$ & يريدن \\
\hline.$- .1 .91 *$ & $\cdot / T F V^{*}$ & $\cdot / 19 \Delta^{*}$ & & & & ضر يب استاندارد نشده (b) \\
\hline \multirow[t]{2}{*}{.$- / .9 \% *$} & . Irr** & $\cdot|F| V^{*}$ & & & & ضريب استاندارد شده (Beta) \\
\hline & & & ఎ99 & $V F / 9 T V$ & $\cdot / T V F$ & لى لى رفتن \\
\hline$-.|| \uparrow \mid *$ & $-\cdot / 19 \cdot *$ & $\cdot / r r * *$ & & & & ضر يب استاندارد نشده (b) \\
\hline \multirow{2}{*}{$-\cdot / 1 \cdot r^{*}$} & $-\cdot / r F A^{*}$ & 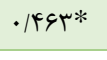 & & & & ضريب استاندارد شده (Beta) \\
\hline & & & $\Delta 99$ & $V \cdot /$ fef & - KAT & سكسكه دويدن \\
\hline$-.1 \cdot 11$ & $-\cdot / 4 r q *$ & $\cdot / r \Delta \Lambda^{*}$ & & & & ضر يب استاندارد نشده (b) \\
\hline \multirow{2}{*}{.$- / . t r$} & $-\cdot / r \vee \Lambda *$ & . 1 \&ra* & & & & ضريب استاندارد شده (Beta) \\
\hline & & & $\Delta 99$ & $r \cdot / 9 \cdot r$ & .1 .90 & بالا رفتن از يله \\
\hline$-\cdot / 1 \Gamma \Lambda^{*}$ & $\cdot 1 \cdot V r$ & $\cdot / \cdot \Delta \Delta^{*}$ & & & & ضريب استاندارد نشده (b) \\
\hline \multirow{2}{*}{$-\cdot / \cdot 9 V^{*}$} &.$/ 190$ & $\cdot / r r q *$ & & & & ضريب استاندارد شده (Beta) \\
\hline & & & $\Delta 99$ & $1 . .1 \cdot 94$ & - Kro & صعود از نردبان \\
\hline.$- / 1 \& F^{*}$ & $\cdot / 19 \Upsilon^{*}$ & $\cdot / r T \cdot *$ & & & & ضر يب استاندارد نشده (b) \\
\hline.$- / 1 \Gamma 9 *$ & $\cdot / r V r^{*}$ & $\cdot 10 \cdot \wedge *$ & & & & ضريب استاندارد شده (Beta) \\
\hline
\end{tabular}

p<*/*ם معنى دارى در سطح * 
جدول ه. تحليل ركر سيون جندمتغيره براى مهارتهاى كنترل شىء با متغيرهاى سن، جنسيت و شاخص تودهُ بدنى (BMI) در كودكان • V_I سال

\begin{tabular}{|c|c|c|c|c|c|c|}
\hline \multicolumn{3}{|c|}{ متغير هاى مستقل } & \multirow{2}{*}{ Df } & \multirow{2}{*}{$\mathbf{F}$} & \multirow{2}{*}{$\mathbf{R}^{2}$} & \multirow{2}{*}{ متغير هاى وابسته } \\
\hline BMI & 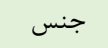 & 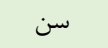 & & & & \\
\hline & & & ब१९ & TV/RGD & $\cdot /|r|$ & دريافت كردن \\
\hline.$/ \cdot r r$ & $\cdot / \Lambda \wedge \vee^{*}$ & $\cdot / r \mu r *$ & & & & ضريب استاندارد نشده (b) \\
\hline \multirow[t]{2}{*}{.$/ \cdot 1 \mathrm{~V}$} & $\cdot / / \Delta \mu *$ & 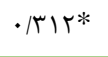 & & & & ضريب استاندارد شده (Beta) \\
\hline & & & ब9६ & $\mathrm{FV} / .99$ & $\cdot / 194$ & ير تاب كردن \\
\hline .1 .94 & $\cdot / / V \cdot *$ & $\cdot|r| \cdot *$ & & & & ضر يب استاندارد نشده (b) \\
\hline \multirow[t]{2}{*}{$\cdot / \cdot v \Delta$} &.$/ 194 *$ & $\cdot / \mu q \cdot *$ & & & & ضريب استاندارد شده (Beta) \\
\hline & & & Q99 & $\Delta \cdot /$ ATF & $\cdot / r \cdot 4$ & ضربه زدن با دست \\
\hline$-\cdot \mid r T I^{*}$ & $-\cdot / 4 \wedge r^{*}$ & $\cdot / \kappa \wedge \cdot *$ & & & & ضريب استاندارد نشده (b) \\
\hline \multirow[t]{2}{*}{$-\cdot / 19 V^{*}$} & $-\cdot|| r \mid *$ & $\cdot / I V F^{*}$ & & & & ضريب استاندارد شده (Beta) \\
\hline & & & ब१९ & $|N / T| r$ & $\cdot / \cdot \wedge \mathrm{F}$ & ضربه زدن با ها \\
\hline$-\cdot / 1 r \Delta^{*}$ & $\cdot / 199 *$ & $\cdot \pi r \Delta *$ & & & & ضريب استاندارد نشده (b) \\
\hline$-\cdot / 114 *$ & $\cdot / 119 *$ & 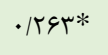 & & & & ضر يب استاندارد شده (Beta) \\
\hline
\end{tabular}

p<•/•ه معنى

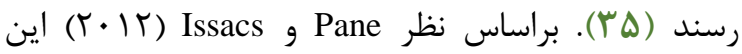
بת

افزايش تبحر موجب حمل بهتر بار ناشى از اضافهوزن و جاقى در كودى مىشود. بهطورى كه اين دو مهارت كمتر

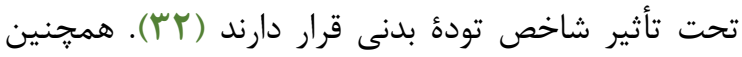
D'Hondt مهارتهايى كه دشوارتر هستند و اجزاى حركتى بيشترى دارند، در كودكان جاق ضعيفتر است. لذا با توجه به آنكه مهارتهاى دويدن و راه رفتن از اجزاى حركتى كمترى دان

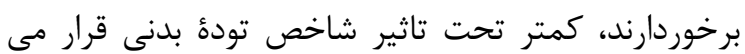

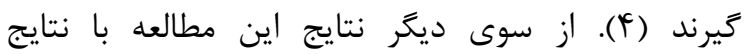
SiahKohian

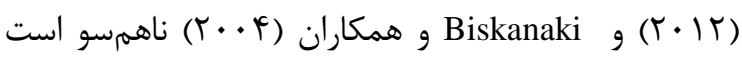

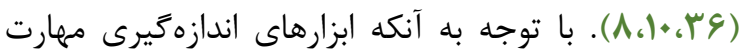
هاى حركتى بنيادى استفاده شده در اين تحقيقات صرفا

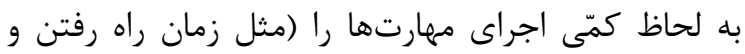

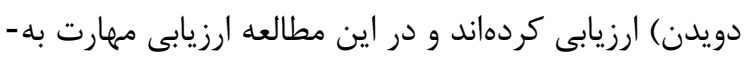

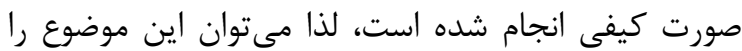
علت ناهمسو بودن اين نتايج درنظر كرفت.

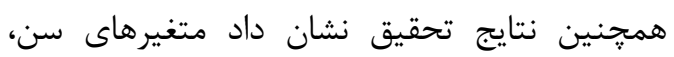
جنسيت و شاخص تودهٔ بدنى تاثير معنىدارى بر مهارت

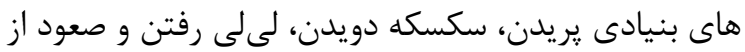

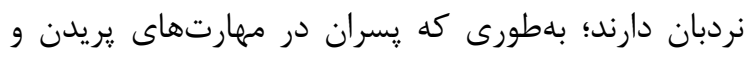

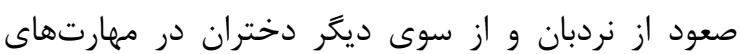

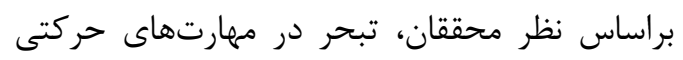

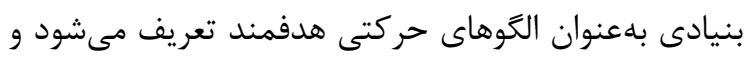

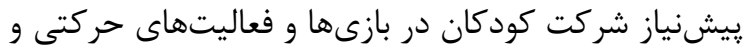
جسمانى مختلف است. از سوى ديخر بهبود اين مهارتهات

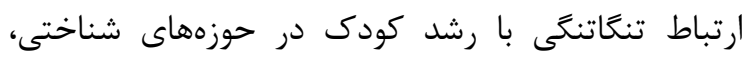
عاطفى و روانى اجتماعى دارد. بنابراين سنجش مهارئ ردارتهاى حركتى در دوران كودكى براى تشخيص تأخيرهاى رشدى أنى دارئ

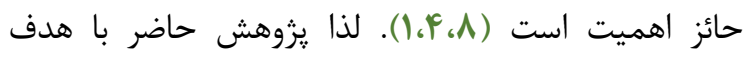

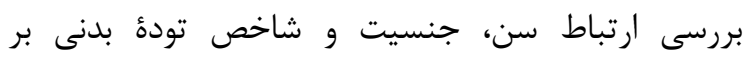

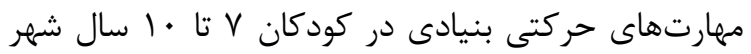
تهران انجام شد. نتايج تحقيق حاضر در ارتباط با مهارت

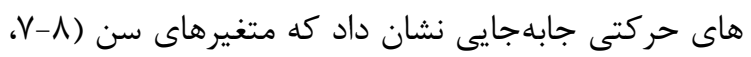

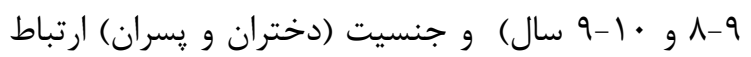
معنى دارى با مهارتهاى راه رفتن و دويدن داشتند؛ اما

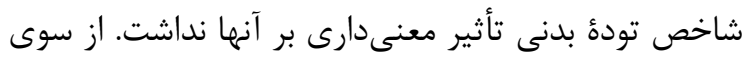

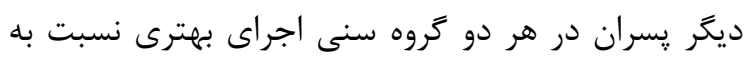
دختران داشتند. نتايج اين قسمت در ارتباط با شاخص درد

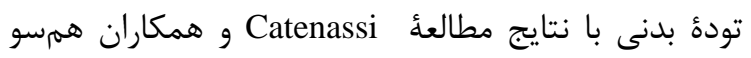

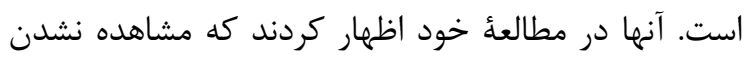

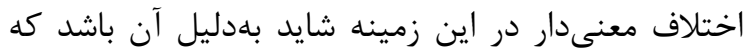
كودكان مهارتهاى راه رفتن و دويدن را زودتر از ديكر دمان

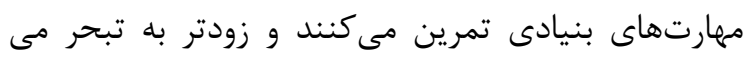


مثل كف پاى صاف و افزايش درد در كودكان مىشود؛ بهكونهاى كه عملكرد كودكان راضعيفتر كرده و فعاليت آنها

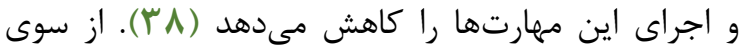

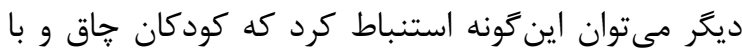

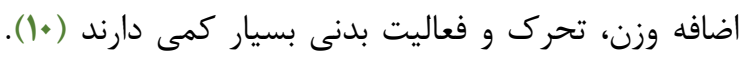
اين امر منجر به كاهش فرصتهایى بازى، يادكيرى و تمرين

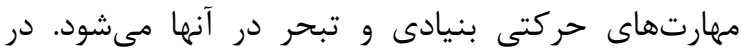

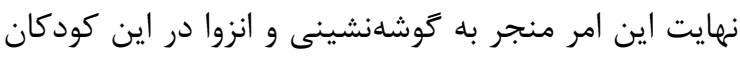
شده و عاقبت مى تواند به مشكلات روانى و جسمانى منتهيى

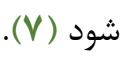

همجنين، نتايج تحقيق حاضر در ارتباط با مهارت

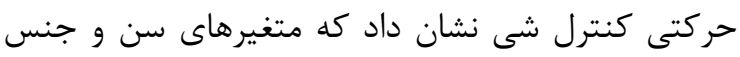

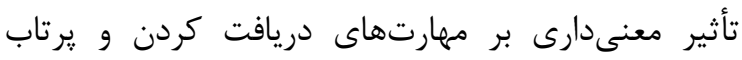

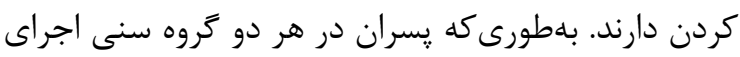

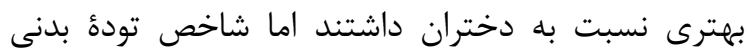

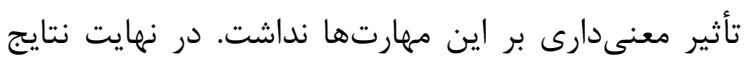
تحقيق نشان داد كه متغيرهاى سن، جنس و شاخص توده

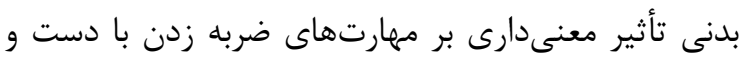

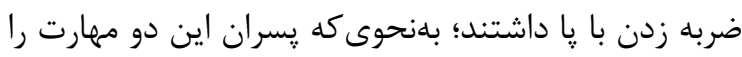

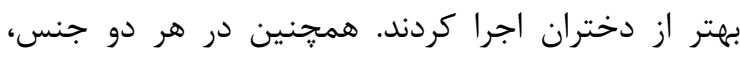
كودكان دجار اضافهوزن و جاقى، عملكرد ضعيفترى نسبت ندان به كودكان با شاخص توده بدنى نرمال داشتند.

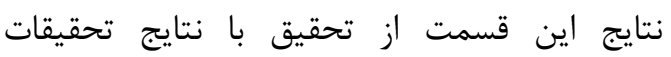
SiahKohian

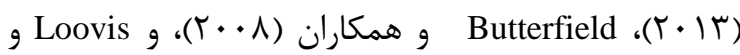

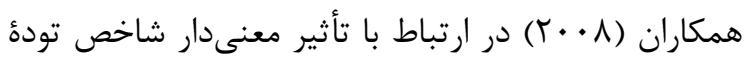

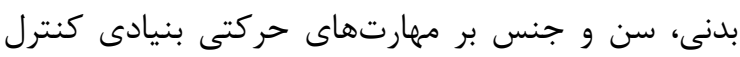

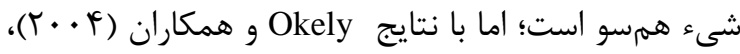
Southal

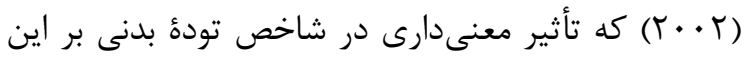

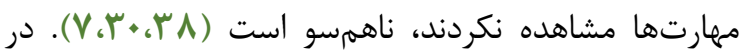

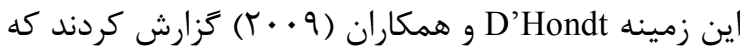
شاخص توده بدنى موجب محدود شدن دامنه حركتى

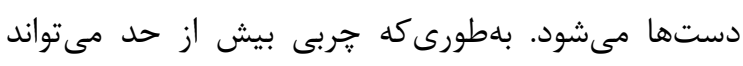

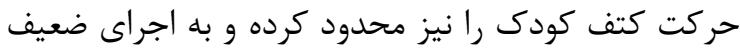
در كودكان جاق و با اضافهوزن منجر شود (F). استفاده نكردن از دستكاه ارزيابى تركيب بدن و محاسبة شاخص

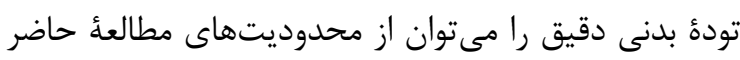

سكسكه دويدن و لى لى رفتن عملكرد بهترى داشتند. علاوه بر اين، در هر دو جنس كودكان دجار اضافهوزن و

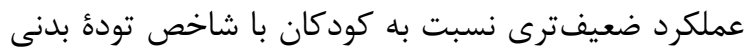

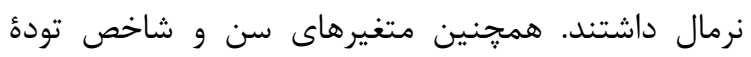

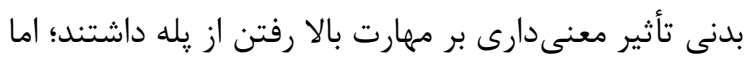

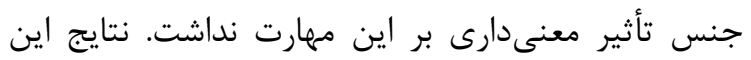

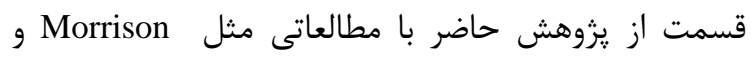

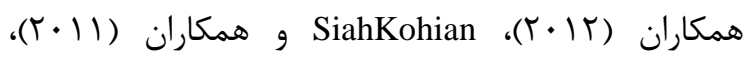
Catenassi

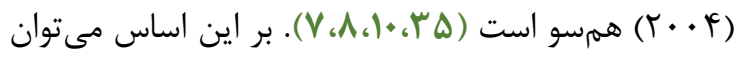

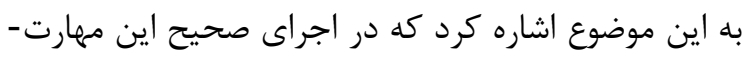

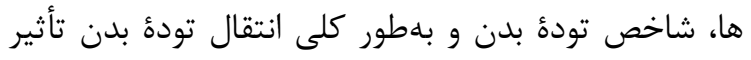

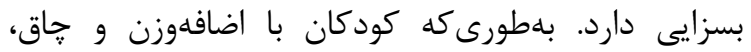
عملكرد ضعيفترى در اين مهارتها دارند.

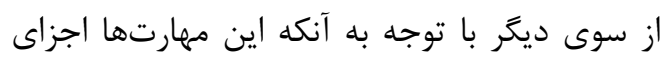

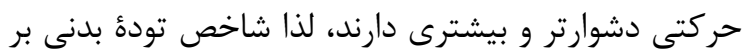

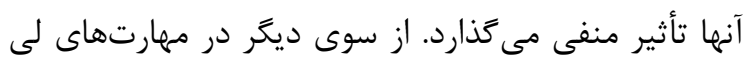

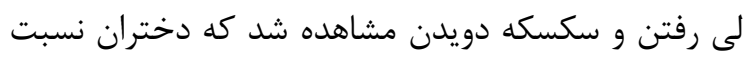

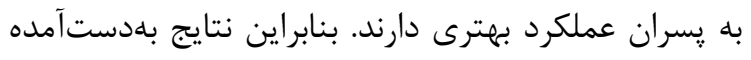

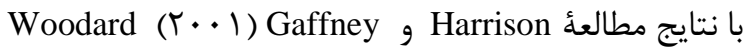

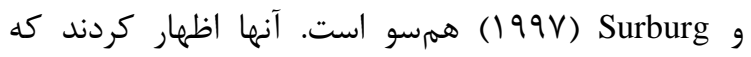

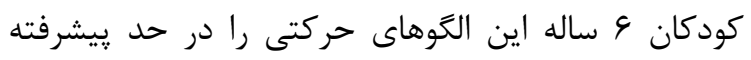

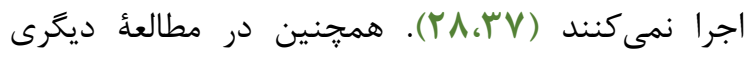
Southal

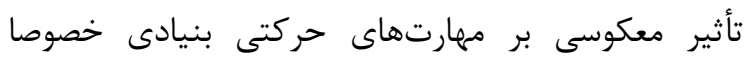

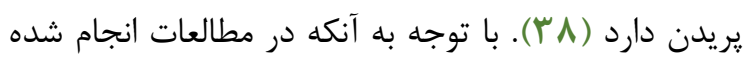

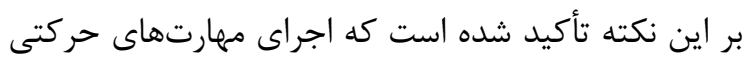
بنيادى كه بهطور همزمان عملكرد اجزاى بالاتنه و يايينتنه

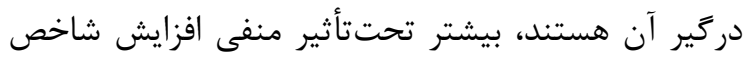

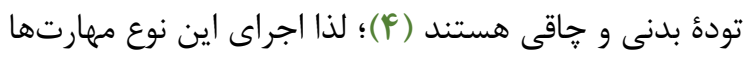

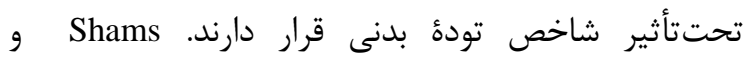

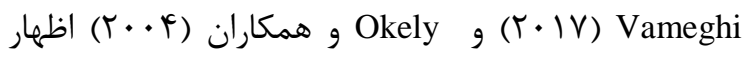
كردند اجراى مهارتهاى بنيادى جابهجايى كه نيازمند

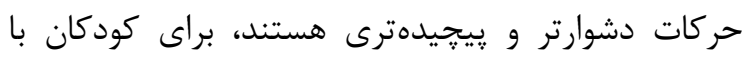

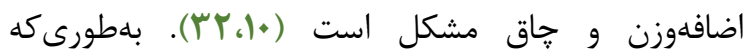
كودكان حاق براى حركت اندام يا تودهٔ بدن خود در مقابل

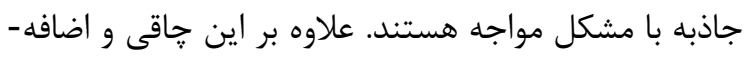

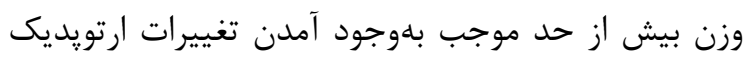




$$
\begin{aligned}
& \text { بنيادى منجر شود (F). از سوى ديكر اين تأثير منفي } \\
& \text { شاخص توده بدنى بر مهارتهاى حركتى بنيادى را مئتوان } \\
& \text { با جند مكانيزم ديكر توضيح داد. به اين صورت كه كودكان }
\end{aligned}
$$

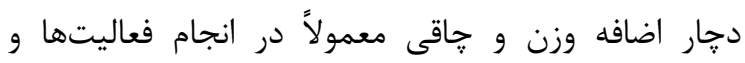

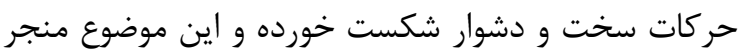

$$
\begin{aligned}
& \text { به كاهش فعاليت بدنى منظم در آنها مىشود و اين امر نيز } \\
& \text { به نوبأ خود منجر به سطح تبحر يايينتر و بيشرفت نكردن }
\end{aligned}
$$

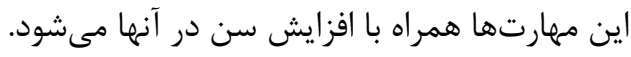

$$
\begin{aligned}
& \text { سياسگزارى } \\
& \text { بدينوسيله از تمام كودكان و والدين آنهري } \\
& \text { شركت در اين يزوهش تشكر و قدردانى مى كنيم. } \\
& \text { تعارض در منافع } \\
& \text { بين نويسندگان تعارضى در منافع زَارش نشده }
\end{aligned}
$$

\section{References}

1. Dietz H. Health consequences of obesity in youth: childhood predictors of adult disease. Pediatrics. 1998;101(2):518-25.PMid:12224658

2. World Health Organization. Obesity:Preventing and managing the global epidemic, Report of WHO Consultation on Obesity, Geneva, 3-5 June, 1997; 1998. Search Report.

3. Ogden CL, Carroll MD, Curtin LR, McDowell MA, Tabak CJ, Flegal KM. Prevalence of overweight and obesity in the United States, 1999-2004. Jama. 2006;295(13):1549-55 . https://doi.org/10.1001/jama.295.13.1549 PMid:16595758

4. D'Hondt E, Deforche B, De Bourdeaudhuij I, Lenoir M. Relationship between motor skill and body mass index in 5-to 10-year-old children. Adapt Phys Activ Q. 2009;26(1):21-37. https://doi.org/10.1123 /apaq.26.1.21

5. Daniels SR. The consequences of childhood overweight and obesity. The future of children. 2006:47-67. https://doi.org/10.1353/foc.2006.0004 PMid:16532658

6. Burke V. Obesity in childhood and cardiovascular risk. Clin Exp Pharmacol Physiol. 2006;33(9):831-7 https://doi.org/10.1111/j.14401681.2006.04449.x PMid:16922816

$$
\begin{aligned}
& \text { بيان كرد و ريشنهاد مىشود در :يزوهشهاى آتى اين } \\
& \text { موضوع مدنظر قرار زيرد. } \\
& \text { نتيجهَ تيرى } \\
& \text { بهطوركلى نتايج اين مطالعه نشان داد شاخص توده } \\
& \text { بدنى، سن و جنس تأثير معنى دارى بر اجراى مهارتهاى } \\
& \text { حركتى بنيادى دارند. اين نتايج با يافتهها و نتايج مطالعات } \\
& \text { ديخرى مطابقت دارد كه براساس هر دو اندازهخيرى دياس }
\end{aligned}
$$

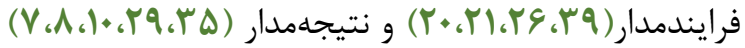

$$
\begin{aligned}
& \text { در اين زمينه انجام شدهاند. لذا اين نتايج معمولا از ديدگاه }
\end{aligned}
$$

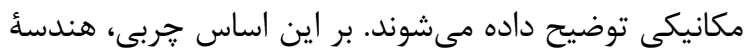

$$
\begin{aligned}
& \text { بدن را تحت تأثير قرار داده و توده قسمتهاى مختلف دئ بدن }
\end{aligned}
$$

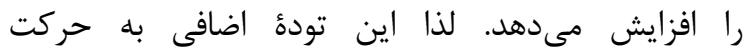

$$
\begin{aligned}
& \text { بيومكانيكى غيرمؤثرى منجر ميىشود. اين امر نيز همان }
\end{aligned}
$$

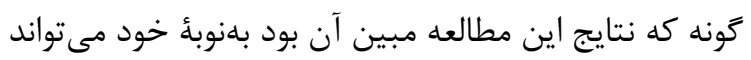

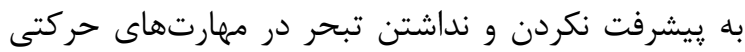

7. Okely AD, Booth ML, Chey T. Relationships between body composition and fundamental movement skills among children and adolescents. Res Q Exerc Sport. 2004;75(3):238-47 https://doi.org/10.1080/02701367.2004.106091 $57 \quad$ PMid: 15487288

8. Siahkouhian M, Mahmoodi H, Salehi M. Relationship between fundamental movement skills and body mass index in 7-to-8 year-old children. World Appl Sci J. 2011;15(9):1354-60.

9. Barsh GS, Farooqi IS, O'rahilly S. Genetics of body-weight regulation. Nature. 2000;404 (6778) :644 .https://doi.org/10.1038/35007519 PMid:10766251

10. Morrison KM, Bugge A, El-Naaman B, Eisenmann JC, Froberg K, Pfeiffer KA, et al. Inter-relationships among physical activity, body fat, and motor performance in 6-to 8-yearold Danish children. Pediatr Exerc Sci. 2012;24 (2):199-209 https://doi.org/10.1123/pes.24.2.199 PMid:22728412

11. Must A, Tybor J. Physical activity and sedentary behavior: a review of longitudinal studies of weight and adiposity in youth. Intl $\mathbf{J}$ Obs. 2005;29:84-96 https://doi.org/10.1038/sj.ijo.0803064 
12. Cools W, De Martelaer K, Samaey C, Andries C. Movement skill assessment of typically developing preschool children: A review of seven movement skill assessment tools. J Sports Sci Med. 2009;8(2):154. PMC3761481

13. Cools W, De Martelaer K, Samaey C, Andries C. Fundamental movement skill performance of preschool children in relation to family context. J Sports Sci Med. 2011;29(7):649-60. https://doi.org/ 10.1080/02640414.2010.551540

14. Gallahue D, Ozmon J. Goodway J. Understanding motor development: infants, children, adolescents and adults. 7nd ed. Pennsylvania (NY):Mc Graw Hill Publisher; 2012.

15. Gabbard CP. Lifelong motor development. 6nd ed. Birmingham: Pearson Publications; 2012. PMC3295850

16. Hardy LL, King L, Farrell L, Macniven R, Howlett S. Fundamental movement skills among Australian preschool children. J Sci Med Sport. 2010;13(5):503-8. https://doi.org/10.1016/j.jsams.2009.05.010 PMid: 1985052

17. Akbari H, Abdoli B, Shafizadeh M, Khalaji H, Hajihosseini S, Ziaee V. The effect of traditional games in fundamental motor skill development in 7-9 year-old boys. Iran J Pediatr. 2009;19(2):123-9.

18. Stodden DF, Goodway JD, Langendorfer SJ, Roberton MA, Rudisill ME, Garcia C, et al. A developmental perspective on the role of motor skill competence in physical activity: An emergent relationship. Quest. 2008;60(2):290306.

https://doi.org/10.1080/00336297.2008.104835 $\underline{82}$

19. Barnett L, Van Beurden E, Morgan P, Brooks L, Beard J. Does childhood motor skill proficiency predict adolescent fitness? Med Sci Sports $\quad$ Exerc. 2008;40(12):2137. https://doi.org/10.1249/MSS.0b013e31818160d 3 PMid:18981934

20. Loovis EM, Butterfield SA, Bagaka's JG. Development of catching by children in kindergarten to grade 8: a multicohort longitudinal study. Percept Mot Skills. 2008;107(1):121-8. https://doi.org/10.2466/pms.107.1.121-128 PMid:18986040

21. Loovis E, Butterfield S, editors. Striking development by children in grades K-8: A multicohort longitudinal study. Res Q Exerc Sport; 2006;29-33.
22. Payne G, Isaacs L. Human motor development a lifespan approach. 9nd ed. Pennsylvania (NY):Mc Graw Hill Publisher; 2016.

23. Isaacs LD. Effects of ball size, ball color, and preferred color on catching by young children. Percept Mot Skills. 1980;51(2):583-6. https://doi.org /10.2466/pms.1980.51.2.583 PMid:7443379

24. Loovis EM, Butterfield SA. Influence of age, sex, balance, and sport participation on development of catching by children grades K8. Percept Mot Skills. 1993;77(3):1267-73. https://doi.org/ 10.2466/pms. 1993.77.3f.1267 PMid:8170777

25. Butterfield SA, Loovis EM. Influence of age, sex, balance, and sport participation on development of kicking by children in grades K-8. Percept Mot Skills. 1994;79(1):6917.https://doi.org/10.2466 /pms.1994.79.1.691 PMid:7808911

26. Butterfield SA, Loovis EM. Influence of age, sex, balance, and sport participation on development of throwing by children in grades K-8. Percept Mot Skills. 1993;76(2):459-64. https://doi.org /10.2466/ pms.1993.76.2.459 PMid:8483657

27. Toole T, Kretzschmar JC. Gender differences in motor performance in early childhood and later adulthood. Women in Sport and Physical Activity Journal. 1993;2(1):41-71 https://doi.org/ 10.1123/ wspaj.2.1.41

28. Woodard RJ, Surburg PR. Fundamental gross motor skill performance by girls and boys with learning disabilities. Percept Mot Skills. 1997;84(3):867-70.

https://doi.org/10.2466/pms.1997.84.3.867 PMid:9172195

29. Robertson SM, Cullen KW, Baranowski J, Baranowski T, HU S. Factors related to adiposity among children aged 3 to 7 years. J Am Diet Assoc. 1999;99(8):938-43. https://doi.org/10.1016/S0002-8223(99)00224$\underline{2}$

30. Butterfield SA, Lehnhard RA, Coladarci T. Age, sex, and body mass index in performance of selected locomotor and fitness tasks by children in grades K-2. Percept Mot Skills. 2002;94(1):80-6

https://doi.org/10.2466/pms.2002.94.1.80 PMid:11883593

31. Shahshahani S, Vameghi R, Azari N, Sajedi F, Kazemnejad A. Comparing the results of developmental screening of 4-60 months old 
children in Tehran using ASQ \& PDQ. Iranian Rehabilitation Journal. 2011;9:3-7.

32. Shams A, Vameghi R. Effect of age and body mass index on performance quality of motor skills among children with 3-5 years-old. J Shahrekord Univ Med Sci. 2017;19(5):1-13

33. Haywood K, Gatchell N. Life span motor development. 6nd ed. Champaign (IL): Human kinetic Publication; 2014.

34. Loovis M, Ersing F. Assessing and programming gross motor development for children. Bloomington, (IN): College town Press; 1979.

35. Catenassi FZ, Marques I, Bastos CB, Basso L, Ronque ERV, Gerage AM. Relationship between body mass index and gross motor skill in four to six year-old children. Rev Bras Med Esporte. 2007;13(4):227-30 https://doi.org/10.1590/S1517$\underline{86922007000400003}$
36. Biskanaki F, Panagiotou A, Papadopoulou S, Spiridou N, Gallos G, Gill J, et al. Ôhe effect of sex and obesity on specific motor skills of Greek children aged 8 years old. Pakistan J Med Res. 2004;3:121-6.

37. Harrison AJ, Gaffney S. Motor development and gender effects on stretch-shortening cycle performance. J Sci Med Sport. 2001;4(4):406-1 https://doi.org/10.1016/S1440-2440(01)80050-5

38. Southall JE, Okely AD, Steele JR. Actual and perceived physical competence in overweight and nonoverweight children. Pediatr Exerc Sci. 2004;16(1):15-24 https://doi.org/10.1123/pes.16.1.15

39. Vameghi R, Shams A, Dehkordi PS. The effect of age, sex and obesity on fundamental motor skills among 4 to 6 years-old children. Pakistan journal of medical sciences. 2013;29(2):586-9 . https://doi.org/10.12669/pjms.292.3069 PMC3809260 